Історико-політичні проблеми сучасного світу: Збірник наукових статей. - Чернівці: Чернівецький національний університет, 2020. - T. 42. - C. 173-179

DOI: $10.31861 / \mathrm{mhpi} 2020.42 .173-179$

УДК 32.019.51:81
Modern Historical and Political Issues: Journal in Historical \& Political Sciences. - Chernivtsi: Chernivtsi National University, 2020. - Volume. 42. - pp. 173-179 DOI: $10.31861 / \mathrm{mhpi} 2020.42 .173-179$

\title{
Аспект функції впливу мовної гри у політичному дискурсі
}

У статті проаналізовано комунікацію політичного дискурсу. Підкреслено те, що політики, не дотримуючись основних комунікативних законів, порушують принципи спілкування, встановлюючи власні нововведені правила мовної гри. Проаналізовано структурний логічний ланцюжок політичної комунікації: інтенція - стратегія - тактика - засоби реалізації. Розглянуто інтенцію мовної гри як точку активізації когнітивно-комунікативної діяльності для досягнення цілей у спроєктованих стратегіях і тактиках політиків. Природа інтенції зумовлює застосування засобів реалізації лінгвопрагматичного потенціалу функцій мовного впливу: прохання, спонукання, наказ, переконання. Зосереджено увагу на застосуванні політиками мовних засобів для маніпулювання в політичному дискурсі. Відзначено важливість застосовування лексем сильного впливу, вдалих фразеологізмів та метафор, які ефектно створюють шарм каламбурного характеру промови й викристалізовують репрезентативний образ політика.

Ключові слова: політичний дискурс, комунікативні закони, мовна гра, функції впливу, політичне маніпулювання.

\section{Functional Aspects of Language Games in Political Discourse}

The article analyzes various aspects of communication in political discourse. One of its major arguments says that politicians who disrespect major rules of communication violate the basic principles of interaction, namely in that they introduce their own new patterns of language games. Adequate principles of interaction are an indispensable requirement for political discourse as such in that they guarantee efficient communication and help avoid conflicts. Such principles are based on general rules of communication. The article underlines the importance of a structual logical chain of political communiction along the following lines: intention - strategy - tactic - means of realization.

In general, human beings acquire languages according to basic linguistic forms and models. The Austrian philosopher L. Wittgenstein introduced the term "language game". In a similar vein, the Swiss linguist F. de Saussure established a link between language and the sphere of games in that he compared the systems of natural languages to the rules of chess. The language games of political discourse are represented by imperative intentions, emotive senses and various means of the manipulative use of linguistic units; they usually focus on factors of impact.

The article discusses the intentions of language games as a point of activization of cognitive and communicative activities for the achievement of goals related to strategies and tactics of politicians. The nature of these intentions exerts impact on the realization of the linguo-pragmatic potential of the functions of perlocutionary linguistic acts (requests, orders, etc.). The perlocutionary functions of language are the basis of political manipulation which manifests itself as a systematic combination of traditional political instruments with contemporary communicative approaches to various aspects of the manipulative impact on political consciousness and behavior. Average citizens who react to political discourse automatically take part in broader intellectual and communivative activities; they also demonstrate their own participation in political processes. Therefore political discourse has an impact on the formation and development of civic society and its relations to the state.

As a rule, politicians develop their communicative strategies along programs and platforms that are designed for central subjects of the political process (the government, political parties and leaders).

\footnotetext{
${ }^{1}$ Кандидат філологічних наук, директор Центру вивчення творчої спадщини Івана Франка, філософський факультет Київського національного університету імені Тараса Шевченка, Україна. E-mail: maiia. moser.ua@gmail.com; http://orcid.org/0000-0002-3876-0430.
} 
This limited circle of addressees causes a certain lack of efficiency that should be corrected inasmuch as the ultimate goal of any communicative strategy should be a certain change of the addressee's worldviews.

Political tactic is an important component of political communicative technologies. Political communicative activities include various aspects of tactical measures and methods that start on a local level and go viral according to strategically devised lines.

In this setting, specific political texts with their particular pragmatic implications appear to be units of political discourse with their own semiotic structure. Politicians create messages based on their world views and ideologies. The role of the addressee should be understood as a priority in political communicative acts that are usually characterized by polemics, a high degree of axiology and persuasiveness.

The article focusses on linguistic tools that politicians use in order to manipulate the electorate. To influence the electorate, politicians use manipulative linguistic items on the lexical, idiomatic and metaphorical level. In political discourse, such linguistic items often turn into stereotypical linguistic tools of particular politicians that leave their mark on the electorate's ideas of their values and beliefs. The article emphasizes the importance of the use of "strong" linguistic items that help create, in the best case, an image of the politician that includes humoristic associations with his or her individual professional language.

Keywords: political discourse, rules of communication, language game, functions of communicative impact, political communication.

Постановка проблеми. Основоположною складовою демократії є політичний дискурс, що дає змогу громадянам обирати 3-поміж різних підходів до вирішення державотворчих проблем той варіянт, який наводить найпереконливіші аргументи на їхню користь.

Політичний дискурс - (від лат. discursus - міркування, доказ) - це сукупність мовленнєвих актів здійснюваних у політичній сфері з метою висловлення, обстоювання та поширення певних уявлень і переконань².

У політичних інституціях усі дискурсивні акти відбуваються за участю взаємодіючих суб'єктів, насамперед політиків, урядовців та представників громадських організацій. Найпоширенішими жанрами політичного дискурсу є політичні комунікації парламентських дебатів, публічних виступів політиків, партійних і виборчих програм партій та окремих кандидатів.

Аналіз досліджень 3 даної проблематики. Необхідною та безумовною вимогою політичного дискурсу насамперед $\epsilon$ відповідні принципи спілкування, що забезпечують ефективну неконфліктну комунікацію. Регулятором неконфліктності виступають принципи спілкування, які скеровують «комунікативну поведінку обох сторін у ході спілкування і базуються на конкретних комунікативних категоріях (комунікативна мета, комунікативний намір) та критеріях (критерій істинності, критерій щирості) ${ }^{3}$. Такі принципи спілкування зреалізовуються за дотримання найзагальніших правил - комунікативних законів.

Комунікативні закони, які складалися в процесі цивілізаційного розвитку суспільства відображають «найзагальнішу об'єктивну закономірність процесу комунікації, що виявляється у межах неконфронтативного дискурсу і неконфронтативних стратегій комунікації» ${ }^{4}$. На жаль, за умови поставленого завдання - досягнення цілей - політики, не дотримуючись основних комунікативних законів, порушують принципи спілкування, встановлюючи нововведені власні правила мовної гри.

Інтелектуальні механізми мовної гри, порушувані такими дослідниками як Л. Вітгенштайн, Ю. Габермас, М. Гайдегтер, Б. Рассел, Дж. Серль, Ф. де Соссюр ще в ХХ ст., лежать в основі філософської проблеми з приводу співвідношення мови й світу.

Австрійський філософ Л. Вітгенштайн вперше ввів термін «мовна гра», відштовхуючись од базових мовних форм та моделей, за допомогою яких людина вивчає мову. За твердженням

\footnotetext{
2 Левенець Ю. голова редколегії, Шаповал Ю. заступник голови (2011), Політична енциклопедія, Київ, Парламентське видавництво, с. 219.

3 Гамова Г. (2007), “Ділове спілкування і мовленнєва діяльність“, Сучасна педагогічна риторика, теорія, практика, міжпредметні зв’язки, Збірник наукових праць за матеріалами наукового семінару, Ред. Космеда Т., Львів, ПАІС, с. 34-45.

${ }^{4}$ Бацевич Ф. (2007), Словник термінів міжкультурної комунікації, Київ, Довіра, с. 56.
} 
Л. Вітгенштайна «увесь процес уживання слів у мові можна репрезентувати як одну із тих ігор, за допомогою яких діти опановують рідну мову. Я називатиму ці ігри «мовними іграми» й говоритиму інколи про певну примітивну мову як про мовну гру» ${ }^{5}$.

Проводячи аналогію між мовою та грою, мовну гру зі грою в шахи зіставляв засновник структуралізму - швейцарський лінгвіст Ф. де Соссюр, оскільки і для шахів, і для мови актуальними $\epsilon$ наступні поняття: «система», «значущість, «правило», «ходи» 6 .

Метою і завданнями статті є дослідження специфічної концепції політичних мовних ігор на основі загального концепту мовної гри в політичному дискурсі. Для цього необхідно дослідити сполучні ланки політичної комунікації між політичним текстом та контекстом, у якому суб'єкт політики, передаючи певне повідомлення, дотримується специфічної вербальної поведінки та використовує функції впливу мовної гри у політичному дискурсі. Слід провести аналіз політичних текстів щоб побачити, які саме типи та жанри текстів використовують політики для впливу на свідомість потенційних виборців.

Методологічну основу нашого дослідження становлять принципи науковості та системності, які насамперед включають критичний аналіз літературних джерел та узагальнення публічної тематичної інформації ЗМІ за допомогою комплексного підходу. Окрім загальнонаукових також використано спеціальнонаукові методи: лінгвістичні та методи соціальної інженерії.

Виклад основного матеріалу дослідження. Мовна гра політичного дискурсу, представлена спонукальними інтенціями, емотивними смислами, різними засобами маніпулятивного використання мовних одиниць, насамперед зосереджується у функиії впливу. Наразі більшість повідомлень політичного дискурсу не є нейтральними, без елементів впливу на масову аудиторію. Процес інформування електорату супроводжується мовними та мовленнєвими прийомами, що стимулюють певну реакцію на передану інформацію.

У нашому дослідженні ми розглянемо інтенцію мовної гри як точку активізації когнітивнокомунікативної діяльності для досягнення цілей у спроєктованих стратегіях і тактиках політиків, оскільки вона структурує логічний ланщюжок політичної комунікаиї̈: інтенція стратегія - тактика - засоби реалізації. Природа інтенції зумовлює застосування засобів реалізації лінгвопрагматичного потенціалу функиій мовного впливу: прохання, спонукання, наказ, переконання.

Функції мовного впливу складають основу природи політичного маніпулювання, яке зумовлює системну інтеграцію традиційних політичних інструментів зі сучасними комунікативними підходами маніпулятивного впливу на політичну свідомість та поведінку. Л. Кочубей в політиці виокремлює маніпулятивні технології та визначає їх як діяльність найманого професійного колективного суб'єкту в сфері політики й управління, з вирішення завдань замовника як типової проблеми за допомогою підтверджених попереднім досвідом технологій, які закріплені в певних соціальних методиках ${ }^{7}$ У цьому процесі, на думку І. Рибак, значну роль відіграють саме інформаційно-маніпулятивні технології впливу, які $є$ різновидом політичних технологій та впливають на політичну свідомість і поведінку адресатів. Такі технології ефективно організовують і керують комунікацією між політичними суб'єктами та громадянами, виступаючи трендом розвитку інформаційного суспільства ${ }^{8}$.

Для ефективного впливу на свідомість адресата агент впливу (політик) насамперед здійснює рухи зорієнтовані на взаємозв'язок зі спільнотою, визначальними характерними рисами якої $є$ іiі базові потреби, стани свідомості та властиві ій підсвідомі процеси. Тому в процесі комунікативних зв'язків для мобілізації різних суспільних груп, проведення вербальної політичної діяльності та поширення інформації про неї, створення особливої політичної картини світу відбувається за рахунок маніпулювання суспільною свідомістю. Пересічні громадяни, реагую-

\footnotetext{
5 Витгенштейн Л. (1985), Философские исследования, Новое в зарубежной лингвистике, Выпуск XVI, Москва, Прогресс, с. 79-128.

${ }^{6}$ Соссюр Фердінан де (1998), Курс загальної лінгвістики, Переклад з французької Корнійчук А., Тищенко К., Київ, Основи, с. 36, 113, 140.

${ }^{7}$ Кочубей Л. (2008), Виборчі технології, Київ, Український центр політичного менеджменту. с. 332.

${ }^{8}$ Рибак I. (2012), “Інформаційно-комунікативні виміри сучасного політичного маніпулювання“, Держава і право : збірник наукових праць, Юридичні і політичні науки, Випуск 57, Київ, Інститут держави і права ім. В.М. Корецького НАН України, с. 565-572.
} 
чи на дискурс політиків автоматично включаються в розумово-комунікативну діяльність i, виражаючи власні ідеологічні позиції, демонструють свої аспекти участі в політиці. Ось тут і спрацьовує механізм спонукальної інтенції мовної гри в мовленнєвій діяльності політиків у політичному дискурсі. Таким чином політичний дискурс впливає на формування й розвиток державно-цивільних відносин. За словами Л. Вітгенштайна «мова маскує думку. I маскує так, що 3 зовнішньої форми маски не можна скласти уявлення про форму замаскованої думки, бо форму маски утворено зовсім не для того, щоб із неї можна було впізнати форму тіла» 9 .

Наступним кроком структури логічного ланцюжка політичної комунікації є стратегія. Комунікативна стратегія, метою якої є вплив на емоційну, інтелектуальну та вольову сферу адресата, є найскладнішим і найсуттєвішим елементом політичної діяльності. Успішну комунікативну стратегію політики зазвичай розробляють у вигляді програми чи платформи для центральних суб'єктів політики (державної влади, політичних партій, лідерів), що чітко відображає специфіку діяльності цих суб'єктів.

Проаналізувавши публічні виступи українських політиків, ми відстежили такі найбільш уживані комунікативні стратегії політичного дискурсу: стратегія дискредитації, стратегія ідеалізації, стратегія інтелектуалізації, стратегія заперечення, стратегія мотивації.

Матеріалом нашого дослідження був українськомовний корпус дискурсивних текстів професійного політичного спрямування загальним обсягом близько 47250 слововживань, зібраний за період 32005 р. до 2020 р. До нього ввійшли: блоги найбільш рейтингових політиків, українське суспільно-політичне інтернет-ЗМІ «Українська правда», всеукраїнська суспільнополітична газета «Газета по-українськи», видання центральних органів виконавчої влади України «Урядовий кур'єр».

У політичній комунікації політики, свідомо обравши певну модель комунікативної поведінки, використовують відповідні комунікативні стратегії з такими характерними принципами:

- наявність стратегії забезпечує сильну позицію їі суб’ єкта;

- стратегія окрім планування зумовлює ще й виконання, оскільки передбачає досягнення цілей;

- стратегія спрямована на врахування пріоритетів, адже інколи ресурсна підтримка можлива лише в обмеженому обсязі;

- стратегія покликана компенсувати недостатність ресурсів з допомогою адаптування;

- стратегія забезпечує бачення сьогодення крізь призму майбутнього, збільшуючи й стверджуючи «поле бачення»;

- стратегія враховує всі негативні аспекти, які непередбачувано можуть з’являтися в процесі реалізації, для вирішення яких буде необхідна багатоваріянтність стратегії.

Кінцевою метою будь-якої комунікативної стратегії є корекція моделі картини світу адресата. Якщо комунікативну стратегію усвідомлювати як головний намір, глобальне завдання, то засобом реалізації стратегії є тактика. Оскільки стратегія є метою, а тактика - пї втіленням, то ці два поняття співвідносяться як рід та вид.

Тактика в політичному аспекті є вагомою ланкою технологій політичної діяльності, яка включає в себе всю сукупність тактичних прийомів і заходів, засобів і методів досягнення локальних результатів із їх продуманим і системним застосуванням для реалізація всієї стратегічної лінії ${ }^{10}$.

Ми бачимо такі відмінності між поняттями стратегії політичної комунікації і тактики:

- стратегія розроблена як алгоритм із серії кроків, а тактика передбачає виконання одного чіткого прийому;

- стратегія функціонує в усьому багатовимірному просторі, враховуючи наявність і прихильників, і супротивників, а тактика покликана забезпечити вплив виключно на однодумців;

- стратегія здатна конструювати віртуальний простір, а тактика зорієнтована на реальний простір;

\footnotetext{
9 Вітгенштайн Л. (1995), Tractatus logico-filosoficus, Філософські дослідження, Київ, Основи. URL: www.philsci.univ.kiev.ua/biblio/vitgen.html (дата звернення 15.07.2020).

10 Пойченко А. (1996), Політика: теорія і технології діяльності, Київ, Інститут національних відносин і політології, с. 162.
} 
- за умов багатогранності стратегія покликана врахувати зміну точок зору адресатів, а тактика дотримується однієї із них.

У контексті застосування усієї сукупності тактичних прийомів і заходів, засобів і методів досягнення локальних результатів для реалізації політичної стратегії дієвим інструментом виступає інтенція мовної гри. Дуже важливо звернути увагу на одиниці мови використовувані для відображення думок під час репрезентації політика, бо як сказав Л. Вітгенштайн: «Тільки речення має сенс; тільки в контексті речення назва має значення» ${ }^{11}$.

Отже, саме мова $є$ засобом реалізації у структурі логічного ланцюжка політичної комунікації. У «Філософських дослідженнях» Вітгенштайна чітко вказано: «Сукупність речень $\epsilon$ мовою», «Усі речення рівноцінні», «Світ можна повністю описати цілковито узагальненими реченнями, тобто не підпорядковуючи наперед якихось назв певним предметам» ${ }^{12}$. Таким чином одиницею політичного дискурсу є текст із прагматичною настановою, як специфічна знакова структура із властивою цілісністю та завершеністю.

Політик створює своє політичне інформаційне повідомлення спираючись на власне світосприйняття та політичну уяву. Саме в цей період відбувається інформаційний процес кодування, який грунтується на властивих людських особливостях політика: рівень компетенції, освіти, ерудиції, моральних цінностей та ін.. Та, на жаль, у зв'язку зі суттєвими відмінностями притаманними портретові адресата, у процесі інформаційного декодування політичного повідомлення ефект впливу мовної гри політика послаблюється і не спрацьовує. Позиція адресата в акті комунікації є пріоритетною, тому орієнтація інформаційного повідомлення на нього зобов'язує політика до вдосконалення застосування мовних засобів.

Характерними рисами політичного дискурсу повинні бути полемічність, високий ступінь аксіологічності та переконливості. Варто в такому разі застосовувати лексеми сильного впливу, фразеологізми та метафори, що ефектно створюватимуть шарм каламбурного характеру промови й викристалізовуватимуть репрезентативний образ політика.

Наведемо найбільш яскраві ілюстративні приклади реалій політичного дискурсу з українських 3МI:

- Олег Уруський: «Повітряний старт» може стати для Украйни наиіональною ідеєю» для зацікавлення міжнародних стратегічних партнерів віцепрем'єрміністр (міністр з питань стратегічних галузей промисловості) Олег Уруський вжив поняття «повітряний старт» - тут ідеться про спосіб запуску ракет або літаків із висоти кількох кілометрів, намагаючись прорекламувати вітчизняні досягнення авіапромисловості (Урядовий кур'єр, 21 липня 2020 р.);

- "УУкайнський народ черговий раз побачив смаленого вовка, чи вдасться нам як спільноті взяти його урок $i$ зрозуміти свої обмеження - як плату за свободу» - кандидат державного управління Гурієвська Валентина у статті «Бути вовками» намагається донести до читача психологію міфотворення свідомості сучасного суспільства в сумній тональності (Українська правда, 15 червня 2014 р.);

- «B політиці, як у футболі: можна мати багато завзяття, найбільш «динамівське» із сердець, але бути абсолютно безпорадним перед своїми суперниками» - i далі в статті всіх обговорюваних героїв (Ю. Тимошенко, О. Ляшко, І. Смешко, С. Вакарчук, А. Шарій) змальовано, як гравці футбольного поля, занурюючи читача не в раціональність, а в емотивність викликану захопленням футболом (Українська правда, 3 серпня 2020 р.);

- «Падіння економіки, яке почалося відразу після перемоги ЗЕкоманди, перейшло в піке»одним словом «піке» (вид тангажу, стрімкий політ літака майже вертикально вниз) зневажливо охарактеризовано економіку за правління президента України В. Зеленського (Українська правда, Блог Ю. Луценка, 4 серпня 2020 р.);

- «Влада влаштовуе «дикі таниі» навколо участі Юлії Тимошенко у судових процесах»підкреслено безглуздя поведінки влади в порушених проти Ю. Тимошенко кримінальних справах із політичних мотивів за допомогою популярного терміну, який відображає сучасну компіляцію древніх етнічних гуцульських мотивів, що використала співачка Руслана для створення студійного альбому (Конфлікти і закони, 5 березня 2013 р.);

\footnotetext{
${ }^{11}$ Вітгенштайн Л. (1995), вказ. пр.

${ }^{12}$ Там само.
} 
- «Таємна вечеря» - під такою голосною назвою асоційованою 3 пам’яткою мистецтва світового значення про скандальну кримінальну справу в Українській газеті редактором Михайлом Подоляком розміщено було статтю 3 версією опису отруєння Президента Ющенка (Українська газета, №22 15-21, червня 2005 р.);

- «M'яч протидї COVID-19 зараз на полі місиевої влади» - в період старту передвиборчої кампанії на місцевих виборах, зосередившись на масах і завойовуючи прихильність електорату, застосовують силу впливу на зацікавлених фанатах футболу тематичними асоціативними словами (Українська правда, Блог Т. Бадікова, 10 липня 2020 р.).

Висновки. Дослідивши специфічну концепцію політичних мовних ігор на основі загального концепту мовної гри в політичному дискурсі, ми побачили силу дії політичних текстів повідомлень політиків. Насамперед повідомлення чинить вплив на нервову систему адресата 3 допомогою деякої сукупності сигналів, подразників, яка може бути подана різними способами залежно від систем, які ії видають та сприймають. Для впливу на електорат політики наповнюють тексти відповідними мовними засобами - впливовими лексемами, фразеологізмами та метафорами. У використаних впливових словах виражається прагматична інтенція адресанта. У політичному дискурсі такі слова формують набір стереотипних засобів мови політика, формуючи таким чином ціннісні переконання адресата - потенційного виборця. Провівши аналіз політичних текстів, ми пересвідчилися в тому, що для впливу на свідомість потенційних виборців політики використовують такі експресивні мовні засоби: яскраві образи, естетичні трендові переконання, фанатичні вподобання мас, міфологізми, оцінні контексти, оцінно марковані слова й словосполучення, які функціонують у сучасній мові ЗМІ. Ми дійшли висновку, що успіх політичного дискурсу забезпечує грамотне використання експліцитних текстових категорій у мовній грі. До них відносять впливові лексеми в контексті застосування всієї сукупності тактичних прийомів і заходів, засобів і методів досягнення локальних результатів для реалізації політичної стратегії мовної гри.

Проводячи наше дослідження, ми звернули увагу на те, що інколи політикам, розбудовуючи власну мовленнєву, комунікативну діяльність варто зважати на пораду Л. Вітгенштайна: «Про те, про щзо не можна сказати, треба мовчати» ${ }^{13}$.

\section{Список джерел}

1. Бацевич Ф. (2007), Словник термінів міжкультурної комунікації, Київ, Довіра.

2. Вітгенштайн Л. (1995), Tractatus logico-filosoficus, Філософські дослідження, Київ, Основи. URL: www.philsci.univ.kiev.ua/biblio/vitgen.html (дата звернення 15.07.2020).

3. Витгенштейн Л. (1985), Философские исследования, Новое в зарубежной лингвистике, Выпуск XVI, Москва, Прогресс, с. 79-128.

4. Габермас Ю. (1996), Комунікативна дія і дискурс - дві форми повсякденної комунікації, Переклад з німецької Ситниченко, Л., Першоджерела комунікативної філософії, Київ, Либідь, с. 84-90.

5. Гамова Г. (2007), “Ділове спілкування і мовленнєва діяльність“, Сучасна педагогічна риторика, теорія, практика, міжпредметні зв'язки, Збірник наукових праць за матеріалами наукового семінару, Ред. Космеда Т., Львів, ПАІС, с. 34-45.

6. Кочубей Л. (2008), Виборчі технології, Київ, Український центр політичного менеджменту.

7. Пойченко А. (1996), Політика: теорія і технологї діяльності, Київ, Інститут національних відносин і політології.

8. Левенець Ю., голова редколегії, Шаповал Ю. заступник голови (2011), Політична енциклопедія, Київ, Парламентське видавництво.

9. Рибак I. (2012), “Інформаційно-комунікативні виміри сучасного політичного маніпулювання“, Держава і право : збірник наукових праць, Юридичні і політичні науки, Випуск 57, Київ, Інститут держави і права ім. В.М. Корецького НАН України, с. 565-572.

10.Соссюр Фердінан де (1998), Курс загальної лінгвістики, Переклад з французької Корнійчук А., Тищенко К., Київ, Основи.

\footnotetext{
${ }^{13}$ Вітгенштайн Л. (1995), вказ. пр.
} 


\section{References}

1. Batsevych F. (2007), Slovnyk terminiv mizhkulturnoi komunikatsii, Kyiv, Dovira.

2. Vithenshtain L. (1995), Tractatus logico-filosoficus. Filosofski doslidzhennia, Kyiv, Osnovy, available at : www.philsci.univ.kiev.ua/biblio/vitgen.html (data zvernennia 15.07.2020).

3. Vythenshtein L. (1985), Fylosofskye yssledovanyia. Novoe v zarubezhnoi lynhvystyke, Vypusk XVI, Moskva, Prohress, pp. 79-128.

4. Habermas Yu. (1996), Komunikatyvna diia i dyskurs - dvi formy povsiakdennoi komunikatsii, Pereklad z nimetskoi Sytnychenko L., Pershodzherela komunikatyvnoi filosofii, Kyiv, Lybid, pp. 8490.

5. Hamova H. (2007), "Dilove spilkuvannia i movlennieva diialnist", Suchasna pedahohichna rytoryka, teoriia, praktyka, mizhpredmetni zviazky, Zbirnyk naukovykh prats za materialamy naukovoho seminaru, in Kosmeda T. (ed.), Lviv, PAIS, pp. 34-45.

6. Kochubei L. (2008), Vyborchi tekhnolohii, Kyiv, Ukrainskyi tsentr politychnoho menedzhmentu.

7. Poichenko A. (1996), Polityka: teoriia i tekhnolohii diialnosti, Kyiv, Instytut natsionalnykh vidnosyn i politolohii.

8. Levenets Yu. (holova redkolehii), Shapoval Yu. (zastupnyk holovy) (2011), Politychna entsyklopediia, Kyiv, Parlamentske vydavnytstvo.

9. Rybak I. (2012), "Informatsiino-komunikatyvni vymiry suchasnoho politychnoho manipuliuvannia“, Derzhava i pravo: zbirnyk naukovykh prats, Yurydychni i politychni nauky. Vypusk 57. Kyiv: Instytut derzhavy i prava im. V.M. Koretskoho NAN Ukrainy, pp. 565-572.

10.Sossiur, Ferdinan de (1998), Kurs zahalnoi linhvistyky, Pereklad z frantsuzkoi Korniichuk A, Tyshchenko K., Kyiv, Osnovy. 